Marquette University

e-Publications@Marquette

$7-1-2004$

\title{
MBO Financing Risks And Managers' Use Of Anti- Takeover Measures
}

Sarah Peck

Marquette University, sarah.peck@marquette.edu

Published version. Journal of Applied Business Research, Vol. 20, No. 3 (Summer 2004): 11-30. DOI. (C) 2004 Clute Institute. Used with permission. 


\title{
MBO Financing Risks And Managers' Use Of Anti-Takeover Measures
}

Sarah W. Peck, (E-mail: sarah.peck@mu.edu), Marquette University

\begin{abstract}
In a management buyout (MBO) offer, managers have an incentive to offer stockholders a price low enough to compensate them for the risks of increasing their equity ownership in a highly leveraged buyout firm. As these risks increase, managers are more likely to combine their offer with an anti-takeover measure. These measures do not protect a low offer, but do result in a higher takeover price when managers are unwilling to match a competitive offer. Such measures, then, benefit shareholders.
\end{abstract}

\section{Introduction}

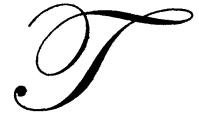

here is an extensive body of research surrounding managers' motivations for adopting anti-takeover measures (see DeAngelo and Rice, 1983; Linn and McConnell, 1983; Dann and DeAngelo, 1988; Maletesta and Walking, 1988; Ryngaert, 1988; Jarrell and Poulsen, 1987, 1988; Karpoff and Maletesta, 1989; McWilliams,1990; Brickley, Coles, and Terry, 1994; Comment and Schwert, 1995; McWilliams and Sen, 1997; and Malezadeh, McWilliams, and Sen, 1998). The earliest of these studies, DeAngleo and Rice (1983), identifies two competing hypothesis for management's motivations for taking anti-takeover actions and their implications for shareholder wealth- (1) the "management entrenchment hypothesis" where management takes such actions to discourage takeover bids to protect their jobs and compensation; and (2) the "bargaining hypothesis" where management uses anti-takeover devices to negotiate for a higher takeover premium for both their shares and those of other shareholders. Subsequent research on the "entrenchment" hypothesis focuses on how management's compensation (including "golden parachutes") and personal stock gains from a possible takeover can influence their decision to adopt anti-takeover measures (see Cotter and Zenner, 1994; Borokhovich, Brunarski, and Parrino, 1997; and Alexander, Barnhart, and Spivey, 2000). While, these studies examine how changes in the level of management's wealth can influence their behavior, they do not investigate how changes in the risks to their wealth can also influence their actions during control contests. This study does.

For this study, I use a sample of management buyout offers (MBO). MBOs are a useful starting point for such an investigation because they are discrete events associated with a large increase in the risk to managers' wealth. In an $\mathrm{MBO}$, managers offer to buyout the public shareholders at a premium over market price. Managers finance these transactions by issuing large amounts of debt in the buyout firm's name and making an additional investment of their own in the firm. Furthermore, they become employed at a firm that is more likely to become bankrupt which could leave them without a job. Thus an MBO causes managers to concentrate their personal wealth in a highly leveraged and thus riskier firm (see Kaplan, 1989; and Andrade and Kaplan, 1998). Management will take on these additional risks if they can purchase the firm at a price that is low relative to firm's post-buyout value. Firm value often increases after the buyout from improvements in the firm's operating efficiency (see Kaplan,1989; Jensen, 1986, 1989; and Smith, 1990).

MBO offers can also attract other bidders. In about a quarter of MBO offers management ends up losing control of the firm and it is eventually taken over by an outside bidder (see Kaplan, 1989; and Peck, 1996). Thus, management sómetimes adopts anti-takeover measures during their attempt to buyout the firm (see Peck, 1996). Here managerial "entrenchment" takes the form, not of protecting management's jobs per se, but rather of protecting managements' offer, since management can only lose control of the firm if they fail to match or trump a higher 
offer. When management uses anti-takeover measures to protect a low offer they hurt public shareholders by denying them the best price for their shares.

Alternatively, managers may find that the risks involved in the MBO are too great and they are better off relinquishing control to a higher bidder. Under this scenario, managers can use an anti-takeover device to bargain for an even higher price for their shares, which incidentally, also benefits other shareholders. In this study, I present evidence that suggests that management more often uses anti-takeover measures as a bargaining device rather than as a way to protect a low offer and that management's motives for adopting anti-takeover measures are positively related to the potential risks that they face if they participate in the MBO.

In addition to showing how changes in the risks management faces can influence their behavior during a control contest, this study makes two other contributions. First, this paper extends the results of Comment and Schwert (1995) that conclude that anti-takeover devices are associated with only mild deterrence and are often used as a bargaining device to obtain a higher takeover price for shareholders. This study provides additional insight into when and why managers will use anti-takeover devices to negotiate for a higher takeover premium. When managers face greater uncompensated risk to their personal wealth, they are more likely to use anti-takeover devices to relinquish control at a higher price than to use them to retain control.

Second, this study adds to prior research that examines factors that explain stock price reactions to antitakeover activity. Prior researchers have examined managerial ownership (see McWilliams,1990; and Boyle, Carter, and Storer,1998) and board composition (see Brickley, Coles, and Terry, 1994; and McWilliams and Sen,1997). This study adds the risk borne by the managers to the potential factors that can potentially explain the stock price reaction to anti-takeover activity.

The paper is organized as follows. Section 2 discuss the results of previous research and further develops the above hypothesis. Section 3 describes the data and the sample. Section 4 documents the positive stock price reaction to announcements that managers have acted to deter a takeover attempt. Section 5 shows that after controlling for other variables, there is a positive relationship between the potential financing risks to managers in the MBO and their decision to adopt anti-takeover measures. Section 6 provides evidence that the decision by the managers to take anti-takeover measures increases the likelihood of a higher offer from an outside bidder. Section 7 examines the relation between anti-takeover activity and the outcome of the buyout. Sections 8 and 9 state my conclusions and include suggestions for future research.

\section{Hypothesis Development And Previous Research}

There are several prior studies on the shareholder wealth effects of anti-takeover actions for more random samples of firms that are not necessarily subject to an MBO offer (see DeAngelo and Rice, 1983; Linn and McConnell, 1983; Dann and DeAngelo, 1988; Maletesta and Walking, 1988; Ryngaert, 1988; Jarrell and Poulsen, 1987, 1988; Karpoff and Maletesta, 1989; McWilliams, 1990; Brickley, Coles, and Terry, 1994; Comment and Schwert, 1995; and McWilliams and Sen, 1997). The "management entrenchment hypothesis" would be associated with a negative stock price reaction to the announcement of anti-takeover actions, whereas the "bargaining hypothesis" would be associated with a positive stock price reaction.

All of the prior studies cited above report a stock price reaction that is either significantly negative or insignificantly different from zero. However, it is likely that firms take anti-takeover measures when there is a higher likelihood that the firm is a takeover target. Thus the announcement of the adoption of an entrenching antitakeover measure ("bad news") can be confounded with the revelation that the firm is a takeover target ("good news") leading to the observation of an insignificant stock price reaction. Those studies that control for this by examining the stock price reaction of anti-takeover measures taken in response to an observable takeover threat find a significant negative stock price reaction, although the magnitude of the reaction is small ranging between $1-3 \%$ (see Dann and DeAngelo, 1988; Ryngaert, 1988; Brickley, Coles, and Terry, 1994; and Comment and Schwert, 1995). Thus the extant evidence suggests that anti-takeover actions are at least associated with mild deterrence of a bidder at the detriment of shareholder wealth. 
Using a sample of MBO offers during a comparable time periods to that of these prior studies, I find a significantly positive stock price reaction to the announcement of anti-takeover actions. While I include antitakeover actions taken both in the presence and absence of another bidder, the results are strongest for actions taken in response to an outside bid. Thus the implications for shareholder wealth for anti-takeover actions taken during an MBO contest are strikingly different than that of other types of takeover contests, which, in turn, suggests that management's motivations for taking anti-takeover actions may also be different.

There are two important ways in which MBO contests differ from other types of takeover contests. First, management is bidding for the firm along with those attempting to takeover the firm. Second, if management wins the firm, their ownership in the buyout firm involves greater risks than that of other bidders. The risks faced by management are created by the financing requirements of the transaction. To take the firm private, managers must purchase all of the outstanding stock held by other shareholders (outsiders) at a premium over its pre-buyout price. Managers can raise the funds for this purchase by (1) debt financing; (2) equity investment by managers; or (3) equity investment by third parties such as buyout specialist firms, eg. Kohlberg, Kravis, and Roberts. Each of these methods of financing creates risk for the managers as the owners of the post-buyout firm. First, debt financing increases the leverage of the firm, which, in turn, increases both the beta and the total volatility of the manager's equity investment. Debt financing also increases the likelihood of financial distress that can lead to the loss of the managers' equity investment as well as their executive positions (see Andrade and Kaplan, 1998). Second, equity investment by managers increases their risk by reducing the diversity of their personal portfolios. Finally, third party participation in the MBO equity carries the risk that managers will lose control of the post-buyout firm. As the dollar amount of the outside stock purchase increases, the risks associated with financing the MBO will increase from any one or all of these three sources of funds.

While other successful bidders, such as buyout specialists and managers of other corporations (these are the most common types of bidders besides management in buyouts; see Cotter and Peck, 2001), also end up controlling a highly levered and thus more risky firm, the increase in the risk to their personal wealth is likely to be less than managers in an MBO. Buyout specialists usually invest in a diversified portfolio of many buyouts, whereas managers of the MBO are likely to invest only in their firm's buyout. As for corporations, the acquired firm is usually a wholly owned subsidiary that is but one of the firm's projects in its portfolio. Managers of corporations rely on corporate resources for the purchase and so rarely have a direct personal equity investment in the newly acquired subsidiary. In addition, only a fraction of the parent managers' compensation is likely to be effected by the parent firm's investment in the LBO subsidiary (see Cotter and Peck, 2000). This is in sharp contrast to managers involved in an MBO.

As with any other type of investor, managers are willing to take on the risk of an MBO if the price is right. In an MBO the relevant price is that offered to shareholders to take the firm private. If managers can offer a low price/ buyout premium relative to the post-buyout value of the firm, they can increase their return to taking the firm private. As this return increases, they will be more willing to take on the risks created by the financing needed to complete the MBO transaction. Furthermore, as the risks managers face increase, the price that they will want to purchase the firm at needs to be even lower to increase their post-buyout return. Yet, a lower offer is more likely to attract competitive bidders that do not face the same financing risks as the managers (see Lowenstein, 1985; Hirshleifer and Png, 1990; and Peck, 1996). But because the participation in the MBO is potentially riskier, managers will be less willing to match or trump an outsider's higher bid as a way to retain control of the firm. ${ }^{1}$

One way that managers can protect a low offer is to combine the offer with an anti-takeover measure. However, if managers on average use anti-takeover measures to effectively discourage a higher offer, I would expect to observe a negative stock price reaction to the announcements of such measures. But, as mentioned above, the average stock price reaction to the announcements to such measures is positive. Thus this evidence suggests that managers are not using anti-takeover measures to acquire the firm "cheaply."

An alternative explanation suggests a more sophisticated strategy on the part of managers. As the financing risks that management faces in the post-buyout firm increase, management is more apt to attempt to combine a low offer with an anti-takeover device if their low offer is contested. The device may protect the low offer, but in the event it fails, managers can use it to raise the premium from the bidder when they are unwilling to match the 
bidder's price. Using the anti-takeover measure as a bargaining device will allow managers to get the best price for their shares along with other public shareholders. Thus if managers expect that they will eventually lose control of the firm to a higher bidder they can do so on better terms.

In a sample of MBO attempts, I find evidence that supports the latter explanation above. About $44 \%$ of MBOs receive a takeover bid and about $30 \%$ of the time managers adopt anti-takeover measures. Managers are most likely to adopt anti-takeover measures in response to specific takeover bid, i.e., a competitive bid or a preemptive buyout offer, suggesting that most managers do not anticipate that their offer will be contested. Announcements of these measures are associated with a significantly positive stock price reaction and the likelihood of a competitive bid higher than management's offer is higher after managers have taken anti-takeover actions. The use of anti-takeover measures increases the final price offered by a successful competitive bidder but does not increase the likelihood that managers will acquire the firm nor does it decrease the incidence or extent of revisions in management's initial offer which commonly occurs during an MBO contest (see Peck, 1996). Thus the evidence suggests that anti-takeover measures are ineffective in protecting a low offer and that managers are more likely to use these measures as a bargaining device to increase the takeover premium. As a result, anti-takeover actions by managers benefit other shareholders by giving them a higher buyout premium. If managers were able to use these measures simply to seize control at a lower price, other shareholders would be the losers.

I also explore managers' incentives to use anti-takeover measures. I investigate how the potential amount that managers must finance to complete the MBO; pre-buyout firm performance, risk, and size; CEO compensation contracts; the division and concentration of pre-buyout ownership between insiders and outsiders; the size of the initial buyout premium; and the extent of a takeover threat effects the likelihood that managers adopt anti-takeover measures. I find that as the potential amount that managers must finance and its attendant risks increase, managers are significantly more likely to adopt anti-takeover measures. This finding is consistent with my other results and suggests managers are unwilling to match a competitive bid because they face greater risks from participating in the MBO. As a consequence managers resort to using anti-takeover measures as a means for getting the best price for their shares as consolation to losing the contest. I also find that as firm size and the number of competitive bids increases, managers are significantly more likely to take anti-takeover actions. These findings are consistent with that of other studies that find that managers are more likely to take anti-takeover measures when the firm is a takeover target as indicated by both size and a specific takeover threat (see Comment and Schwert, 1995).

\section{The Sample and Data}

An MBO is defined as an announcement by top management of an offer to buy the firm. This includes announcements that may occur after another party has initiated a buyout. The sample includes only those offers made for the entire firm and excludes offers for divisions. The data set used here is an extension of the data used in Peck (1996) and includes $111 \mathrm{MBO}$ attempts between 1984 and 1987 announced in the Wall Street Journal or the Dow Jones News Wire that meet the data requirements of this study.

Using data from the 1980's has two advantages. First, the time frame for this study is similar to that in previous studies on anti-takeover activity so that comparisons can be made (see Jarrell and Poulsen, 1987, 1988; Dann and DeAngelo, 1988; Maletesta and Walking, 1988; Ryngaert, 1988; Karpoff and Maletesta,1989; and Comment and Schwert, 1995). Second, prior studies on the financing of highly leveraged transactions use data from the eighties (see Cotter and Peck, 2001; Kaplan, 1989; and Kaplan and Stein, 1990). Studies with the same time frame and market conditions as this one can provide reasonable estimates of the financing likely in the proposed $\mathrm{MBO}^{2}$

For each firm in the sample, data is collected on the following events for the year prior to the initial buyout announcement and for the two subsequent years or until the firm became private and was no longer reported in the financial press: the initial buyout announcement, anti-takeover actions by management, actions by outside bidders, outside block acquisitions, revisions in management's bid, and the buyout outcome. 
I also collect data on the concentration of management and outside ownership and the composition of the board using the last proxy statement for the year prior to the initial buyout offer. I also use these proxy statements to collect data on the chief executive officer's cash compensation, "golden parachutes," and stock holdings including stock options. Following Cotter and Zenner (1994) this data allows me to calculate the potential change in the CEO's wealth from a takeover. I obtain data on total equity value the month prior to the initial buyout offer using share price and shares outstanding data from either the CRSP or CRSP/NASDAQ tapes, or Standard \& Poor's Monthly Security Owner's Stock Guide. The CRSP or CRSP/NASDAQ tapes are used to collect data to calculate the market adjusted buyout premiums and the stock price reaction to various announcements.

I also collect data on the performance of the firm for a smaller sample where the data is available. Compustat is used to collect data on operating income before depreciation and amortization (EBITDA, item \#13), total sales (item \#12), and total debt (item \# 9) for the first full fiscal year prior to the initial buyout offer (89 firms). I collect data on EBITDA and total sales for the prior ten pre-buyout years when it is available (74 firms). Following Kaplan and Stein (1993), I use this data to calculate the standard deviation of the growth rate in operating margins (EBITDA/sales) as an alternative measure of firm risk.

Table 1 shows that while $85 \%$ of the all offers are management initiated, in only $66 \%$ of the proposed MBOs, are managers successful in taking the firm private and acquiring its ownership. The firm receives a takeover bid in $44 \%$ of the MBOs and managers adopt anti-takeover measures at some point during the buyout contest $30 \%$ of the time. The remainder of the paper investigates management's motives for taking such measures and the consequences of such measures for shareholders.

Table 1: Firm Characteristics For Management Buyout Attempts ${ }^{\text {a }}$

\begin{tabular}{|c|c|}
\hline Firm Characteristic $^{\mathrm{b}}$ & $\begin{array}{c}\text { Number of Firms } \\
\text { (percentage of total sample) }\end{array}$ \\
\hline Number of buyouts that are management initiated & $\begin{array}{c}94 \\
(84.68 \%) \\
\end{array}$ \\
\hline $\begin{array}{l}\text { Average announcement buyout premium }{ }^{\mathrm{c}} \\
\text { (median) }\end{array}$ & $\begin{array}{l}20.96 \% \\
(20.44 \%)\end{array}$ \\
\hline Number of MBOs that receive a takeover bid & $\begin{array}{c}49 \\
(44.14 \%)\end{array}$ \\
\hline Number of firms where management adopts an anti-takeover measure ${ }^{d}$ & $\begin{array}{c}33 \\
(29.73 \%)\end{array}$ \\
\hline Number of successful MBOs & $\begin{array}{c}73 \\
(65.77 \%) \\
\end{array}$ \\
\hline Number of successful takeovers & $\begin{array}{c}24 \\
(21.62 \%) \\
\end{array}$ \\
\hline Total number of $\mathrm{MBOs}$ & $\begin{array}{c}111 \\
(100 \%)\end{array}$ \\
\hline
\end{tabular}

a management buyout attempt is defined as any announcement in which management, either alone or with a group of equity investors, makes an offer to buy the firm. Divisional buyouts are excluded.

b The time period is 12 months before the MBO offer to the date of completion of the buyout or 24 months after the MBO offer in the case of failed buyouts.

c Announcement buyout premium is defined as the summation of abnormal returns on trading days -20 to +1 . Day 0 is the day the initial buyout offer is announced in the Wall Street Journal or came over the Dow Jones News Wire. Abnormal returns are calculated as the difference between realized returns and market-model expected returns. The CRSP (NASDAQ) value-weighted index is used as the market index for CRSP (NASDAQ) firms. The market model is estimated using 200 daily returns 120 days prior to the initial buyout announcement.

d The adoption of an anti-takeover measure is defined as: (1) the rejection an outside offer; (2) litigation of an outside bidder; (3) and adoption of other anti-takeover defenses. Other anti-takeover defenses include adoption of fair price provisions, control related executive pay packages ("golden parachutes"), staggered board amendments, shareholder rights plans ("poison pills"), and defensive restructurings ("crown jewel"). 


\section{Stock Price Reaction And Timing Relative To Initial Buyout Offer}

Anti-takeover measures taken by managers are defined as: (1) rejecting an outside offer; (2) suing an outside bidder; and (3) adopting other types of anti-takeover defenses. The last includes adopting of fair price provisions, control related executive pay packages ("golden parachutes"), staggered board amendments, shareholder rights plans ("poison pills"), and defensive restructurings ("crown jewel defenses"). ${ }^{3}$ I categorize actions by managers as another type of anti-takeover defense only when the news article explicitly states that the managers' actions are intended to deter a takeover attempt. Because managers' expectations of the emergence of a higher outside bid are likely to change throughout the contest, I include anti-takeover measures taken any time during the buyout contest defined as between one year before the initial buyout announcement and up to the completion of the buyout or two years after the initial buyout announcement in the case of failed buyouts.

Table 2 reports the frequency of different ways that managers take anti-takeover actions. This table shows that most often the form of the anti-takeover action takes is either the board's rejection of an outsider's bid or the adoption of some other type of measure. Less often the firm litigates an outside bidder. However, regardless of the way in which management adopts an anti-takeover measure, they are all associated with a significantly positive stock price reaction on announcement.

Table 2: Stock Price Reaction To The Announcement That Anti-Takeover Measures Have Been Adopted: Type Of Measure ${ }^{2}$

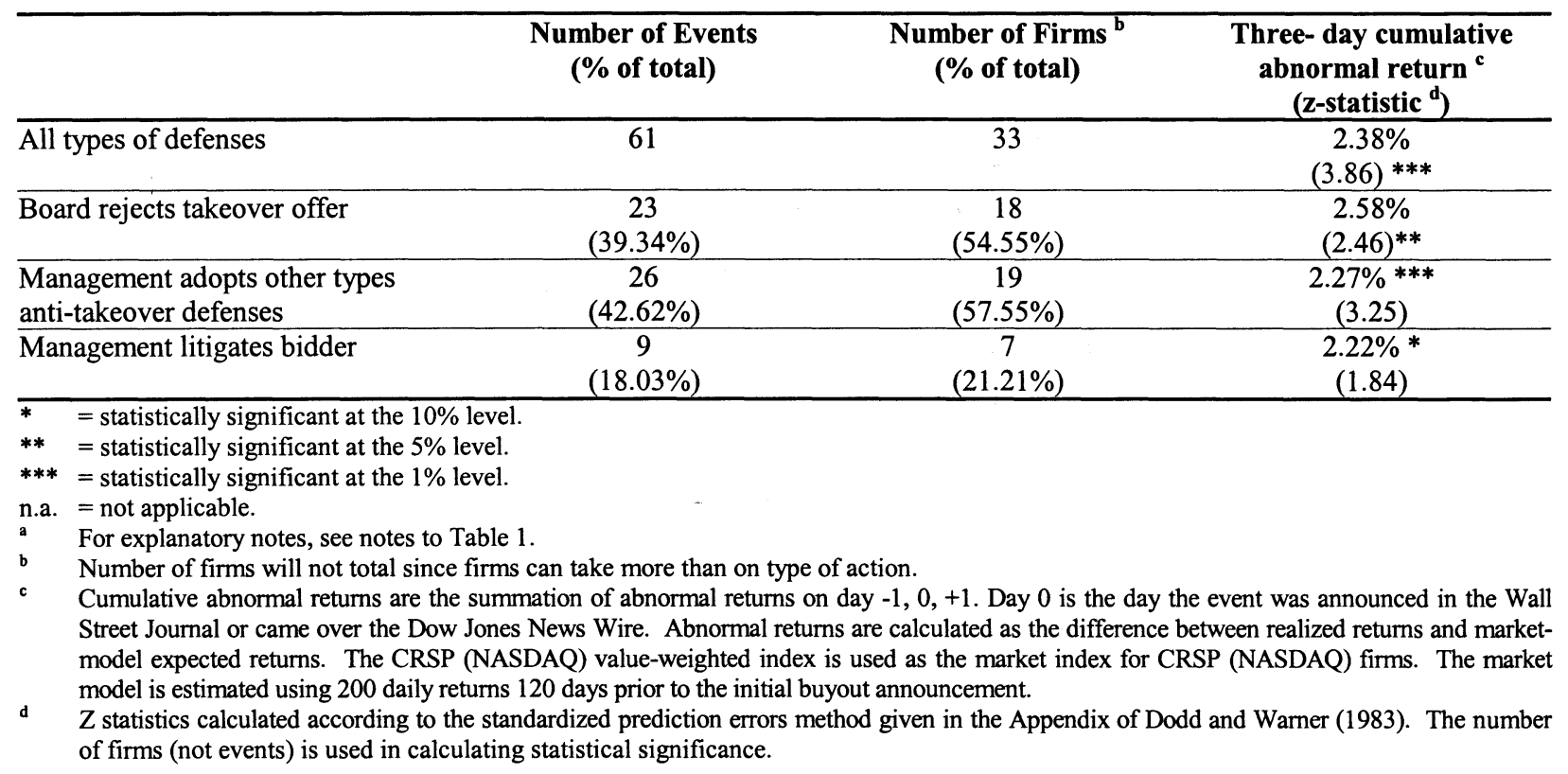

Table 3 shows the timing of the anti-takeover actions relative to the initial buyout offer; whether management or an outsider has made the initial buyout offer; and whether management or an outsider has made a bid when they have not initiated the contest. Panel A of the table shows that $42.42 \%$ of those firms that take antitakeover actions do so before the buyout contest begins. Thus many, but not the majority, of managers anticipate that their offer will be contested.

The vast majority of anti-takeover actions are taken after the buyout contest has been initiated (from Panel A, $75.41 \%$ ). Roughly half of the firms taking actions after the initial buyout offer have buyouts initiated by management (13 firms) and half of these firms have buyouts initiated by an outside bidder (11 firms). Table 3, Panel B, shows that the majority (73.77\%) of anti-takeover actions are taken after a competitive bid has been made 
(whether this is the initial buyout offer or a subsequent competitive bid). This suggests that most often managers do not anticipate that their offer will be contested and take actions in response to a specific takeover threat. Furthermore, the stock price reaction to the announcement of anti-takeover actions taken in response to a competitive bid is statistically significantly positive. This finding is surprising because prior researchers have documented statistically significantly negative stock price reactions to anti-takeover activities taken in response to a specific takeover threat (see Dann and DeAngelo, 1988; Ryngaert, 1988; Brickley, Coles, and Terry, 1994; and Comment and Schwert, 1995). This finding is consistent with managers' eventual use of anti-takeover measures as a negotiating tool for a higher takeover premium. The following sections further explore managers' motives for adoption and eventual use of anti-takeover measures.

Table 3: Stock Price Reaction To The Announcement That Anti-Takeover Measures Have Been Adopted: Timing Of The Adoption Relative To Initial Buyout Offer And Competitive Bids ${ }^{2}$

\begin{tabular}{|c|c|c|c|c|c|c|}
\hline \multicolumn{7}{|c|}{ Panel A: Timing Of The Adoption Of Anti-Takeover Measures Relative To Initial Buy } \\
\hline \multicolumn{3}{|c|}{ Before Initial Buyout Offer: } & \multicolumn{4}{|c|}{ After Initial Buyout Offer: } \\
\hline $\begin{array}{l}\text { Number of } \\
\text { Events }(\% \\
\text { of } 61 \text { total) }\end{array}$ & $\begin{array}{c}\text { Number } \\
\text { of Firms } \\
\text { b }(\% \text { of } \\
33 \text { total) }\end{array}$ & $\begin{array}{c}\text { Three- day } \\
\text { cumulative } \\
\text { abnormal return } \\
\text { (z-statistic) }\end{array}$ & (19 & $\begin{array}{l}\text { Number of } \\
\text { Events (\% } \\
\text { of } 61 \text { total) }\end{array}$ & $\begin{array}{l}\text { Number } \\
\text { of Firms } \\
\text { (\% of } 33 \\
\text { total) }\end{array}$ & $\begin{array}{c}\text { Three- day } \\
\text { cumulative abnormal } \\
\text { return (z-statistic) }\end{array}$ \\
\hline \multirow[t]{5}{*}{$\begin{array}{c}15 \\
(24.59 \%) \\
\end{array}$} & $\begin{array}{c}14 \\
(42.42 \%)\end{array}$ & \multirow[t]{5}{*}{$\begin{array}{l}0.93 \% \\
(1.02) \\
\end{array}$} & $\begin{array}{l}\text { All anti-takeover actions } \\
\text { taken after initial buyout }\end{array}$ & $\begin{array}{c}46 \\
(75.41 \%)\end{array}$ & $\begin{array}{c}23 \\
(69.70 \%)\end{array}$ & $\begin{array}{l}2.98 \% * * * \\
(3.99)\end{array}$ \\
\hline & & & $\begin{array}{l}\text { Management has initiated } \\
\text { buyout and there has been } \\
\text { no competitive bid }\end{array}$ & 1 & 1 & $\begin{array}{l}0.7822 \% \\
(0.24)\end{array}$ \\
\hline & & & $\begin{array}{l}\text { Management has initiated } \\
\text { buyout and there has been a } \\
\text { competitive bid }\end{array}$ & 18 & 12 & $\begin{array}{l}3.1306 \% * \\
(1.60)\end{array}$ \\
\hline & & & $\begin{array}{l}\text { An outside bidder has } \\
\text { initiated the buyout and } \\
\text { management has not yet } \\
\text { made a bid }\end{array}$ & 22 & 9 & $\begin{array}{l}3.0169 \% * * * \\
\quad(3.63)\end{array}$ \\
\hline & & & $\begin{array}{l}\text { An outside bidder has } \\
\text { initiated the buyout and } \\
\text { management has made a bid }\end{array}$ & 5 & 2 & $\begin{array}{l}2.7355 \% \\
(0.81)\end{array}$ \\
\hline \multicolumn{7}{|c|}{$\begin{array}{l}\text { Panel B: Anti-Takeover Measures Adopted In Response To A Takeover Bid } \\
\text { Versus In Anticipation Of A Takeover Bid: }\end{array}$} \\
\hline & & & $\begin{array}{l}\text { Number of Events } \\
\text { (\% of } 61 \text { total) }\end{array}$ & \multicolumn{2}{|c|}{$\begin{array}{l}\text { Number of Firms } \\
(\% \text { of } 33 \text { total })\end{array}$} & $\begin{array}{c}\text { Three- day } \\
\text { cumulative abnormal } \\
\text { return } \\
\text { (z-statistic) } \\
\end{array}$ \\
\hline \multicolumn{3}{|c|}{ No Outside Bid Has Been Made } & $\begin{array}{c}16 \\
(26.23 \%) \\
\end{array}$ & \multicolumn{2}{|c|}{$\begin{array}{c}15 \\
(45.45 \%)\end{array}$} & $\begin{array}{c}0.9248 \% \\
(1.14)\end{array}$ \\
\hline \multicolumn{3}{|c|}{ After An Outside Bid Has Been Made } & $\begin{array}{c}45 \\
(73.77 \%) \\
\end{array}$ & \multicolumn{2}{|c|}{$\begin{array}{c}21 \\
(63.64 \%)\end{array}$} & $\begin{array}{l}3.0343 \% * * * \\
(3.88)\end{array}$ \\
\hline
\end{tabular}

For explanatory notes, see Tables 1 and 2.

b Firm numbers will not total since firms can take more than one anti-takeover action.

\section{Managers' Incentives To Take Anti-Takeover Actions.}

\subsection{Managers' Risks From Financing The Proposed MBO}

As noted earlier the risk to the managers from an $\mathrm{MBO}$ occurs because of the financing required for the transaction. To complete the MBO, managers must purchase stock held by others at a buyout premium. Ideally, I would like to have data on both the details of the financial structure of the proposed MBO and information about the participating managers' personal portfolio holdings. This data would allow me to calculate directly the changes in the managers' beta or volatility of their total wealth as a result of financing the MBO. Unfortunately, this data is not available. When managers propose a MBO they do not disclose the financing details of their initial offer (financing 
details are disclosed in a proxy statement and SEC filings issued only after the contest is resolved) and the personal financial statements of managers are never subject to public disclosure. Thus I use the dollar amount of stock held by outsiders valued at the initial buyout announcement premium as a proxy for the potential financing risks managers' face. As this amount increases, managers either have to invest more and/or have the MBO firm borrow more; either of these methods of financing will create risks for managers participating in the MBO. The total shares outstanding and pre-buyout stock prices are measured one month prior to the buyout announcement. Since not all buyout offers are for cash, I use as a proxy for the premium the cumulative abnormal return for the month before the announcement up to and including the announcement (days -20 to +1 ).

Table 4, Panel A, reports the difference for firms with and without anti-takeover actions in the dollar amount of outstanding stock that must be purchased by the managers at the buyout premium at the time of the announcement. On average, when the managers take actions to deter a takeover, they must purchase $\$ 452.23$ million (median value $=\$ 198.62$ million) worth of stock from outsiders versus $\$ 263.91$ million $($ median value $=$ $\$ 116.92$ million) when managers do not take anti-takeover actions. This difference is statistically significant at the $10 \%$ level ( $5 \%$ level for difference in medians). Because this amount is likely to be driven by the size of the transactions, I also scale this amount by the total MBO firm value. Total firm value is the sum of long-term debt outstanding prior to the buyout announcement and the value of total outstanding stock at the announcement buyout premium. Table 3, Panel A, shows that, on average, managers must finance $88 \%$ (median value $=96 \%$ ) of the MBO value in firms with anti-takeover actions versus $77 \%$ (median value $=87 \%$ ) for firms without such actions. The difference in both the means and medians are statistically significant at the $5 \%$ level.

Table 4: Differences In The Potential MBO Financing Risks For Firms That Have And Have Not Adopted Anti-Takeover Measures (Medians Reported In Parenthesis) ${ }^{2}$

\begin{tabular}{|c|c|c|}
\hline Firm characteristics & $\begin{array}{c}\text { Firms that have adopted anti- } \\
\text { takeover measures } \\
(\mathrm{n}=\mathbf{3 3}) \\
\end{array}$ & $\begin{array}{c}\text { Firms that have not adopted anti- } \\
\text { takeover measures } \\
(\mathrm{n}=78)\end{array}$ \\
\hline \multicolumn{3}{|l|}{ Panel A: The Amount to Be Financed } \\
\hline $\begin{array}{l}\text { Value of outside stock needed to be purchased to } \\
\text { complete the } \mathrm{MBO}^{\mathrm{c}} \text { (millions) }\end{array}$ & $\begin{array}{c}\$ 452.23 \\
(\$ 198.62)\end{array}$ & $\begin{array}{c}263.911^{* b} \\
(\$ 116.92)^{* *}\end{array}$ \\
\hline Investment required relative to value of the $\mathrm{MBO}^{\mathrm{c}}$ & $\begin{array}{c}0.88 \\
(0.96) \\
(\mathrm{n}=26) \\
\end{array}$ & $\begin{array}{c}0.77^{* *} \\
(0.87)^{* *} \\
(\mathrm{n}=63) \\
\end{array}$ \\
\hline \multicolumn{3}{|l|}{ Panel B: Risk Before Buyout } \\
\hline Leverage $^{\mathrm{d}}$ & $\begin{array}{c}0.0013 \\
(0.0008) \\
(\mathrm{n}=26)\end{array}$ & $\begin{array}{c}0.0011 \\
(0.0005) \\
(\mathrm{n}=63)\end{array}$ \\
\hline Equity beta $^{e}$ & $\begin{array}{c}0.79 \\
(0.73) \\
\end{array}$ & $\begin{array}{c}0.66 \\
(0.66) \\
\end{array}$ \\
\hline Implied annual stock return volatility ${ }^{t}$ & $\begin{array}{c}12.44 \\
(12.18) \\
\end{array}$ & $\begin{array}{c}11.66 \\
(11.49)\end{array}$ \\
\hline Standard deviation in growth rate of gross margin ${ }^{g}$ & $\begin{array}{c}1.04 \\
(0.21) \\
(\mathrm{n}=21)\end{array}$ & $\begin{array}{c}2.57 \\
(0.22) \\
(\mathrm{n}=53)\end{array}$ \\
\hline \multicolumn{3}{|l|}{ Panel C: Risk if 75\% Debt Financed } \\
\hline Leverage $^{\mathrm{g}}$ & $\begin{array}{c}0.66 \\
(0.72) \\
(\mathrm{n}=26)\end{array}$ & $\begin{array}{l}0.59^{* *} \\
(0.68)^{*} \\
(\mathrm{n}=63)\end{array}$ \\
\hline Implied equity beta ${ }^{i}$ & $\begin{array}{c}1.75 \\
(1.60) \\
(\mathrm{n}=26)\end{array}$ & $\begin{array}{c}1.21^{*} \\
(1.12)^{*} \\
(\mathrm{n}=63)\end{array}$ \\
\hline Implied annual stock return volatility ${ }^{j}$ & $\begin{array}{c}143.10 \\
(151.63) \\
(\mathrm{n}=26)\end{array}$ & $\begin{array}{c}107.23^{* *} \\
(108.45)^{* *} \\
(\mathrm{n}=63)\end{array}$ \\
\hline $\begin{array}{l}\text { Change in managers' equity }{ }^{k} \\
\text { (millions) }\end{array}$ & $\begin{array}{c}\$ 42.74 \\
(\$ 23.75) \\
(\mathrm{n}=26)\end{array}$ & $\begin{array}{c}7.058^{*} \\
(3.05)^{* *} \\
(\mathrm{n}=63)\end{array}$ \\
\hline
\end{tabular}


a For explanatory notes, see Table 1, except where noted.

b Difference in means tested using a t-test. The samples are tested for unequal variances and then the appropriate standard t-test or Satterthwaite adjusted t-test is used depending on the outcome of the test for unequal variances. Difference in medians tested using a Wilcoxon sum rank test. Differences in frequency of firms tested using a chi-square test.

c Value of outside stock purchased at announcement buyout premium needed to be purchased to complete the MBO is defined as the dollar amount of shares outstanding not beneficially owned by management and directors valued at the initial buyout announcement premium. The total shares outstanding and pre-buyout stock price are measured one month prior to the buyout announcement. Because not all buyout offers are cash, I use as a proxy for the premium the cumulative abnormal return for the month before the announcement up to and including the announcement (days -20 to +1$)$. Total MBO value $=$ value of total outstanding stock purchased at announcement buyout premium plus long term debt outstanding before buyout. Long term debt outstanding before the buyout is Compustat item \# 9 measured the fiscal year prior to the initial buyout announcement.

d Leverage is defined as total long term debt divided by market value of equity one month prior to initial offer plus longer term debt. Long term debt outstanding before the buyout is Compustat item \#9 measured the fiscal year prior to the initial buyout announcement.

e Beta is estimated from market model returns. The CRSP (NASDAQ) value-weighted index is used as the market index for CRSP (NASDAQ) firms. The market model is estimated using 200 daily returns 120 days prior to the initial buyout announcement.

f Annualized volatility is estimated following Yermack (1995), and is estimated as the square root of the sample variance of daily logarithmic stock returns during the last 200 daily returns 120 days prior to the initial buyout announcement, multiplied by 254 , the number of trading days in a typical year.

$\mathrm{g}$ Standard deviation in growth rate of gross margin is defined as the standard deviation of the annual growth rate in (EBITDA/total sales) using up to 10 years of data for the fiscal years prior to the $\mathrm{MBO}$ announcement. EBITDA is Compustat item \#13 and total sales is Compustat item $\# 12$.

h Amount to be financed is equal to value of outside stock purchased at announcement buyout premium. Thus leverage when buyout is $75 \%$ debt financed $=(75 \% \times$ Value of outside stock purchased at announcement buyout premium + long term debt outstanding before buyout $) /$ (Value of total outstanding stock purchased at announcement buyout premium plus long term debt outstanding before buyout). Long term debt outstanding before the buyout is Compustat item \#9 measured the fiscal year prior to the initial buyout announcement.

i Pre-buyout asset betas are determined by using book value of long term debt one year prior to the buyout and market value of total outstanding equity valued at the stock price one month prior to the buyout announcement for the weights of debt and equity. Following Kaplan and Stein (1990) asset betas are determined using the market model estimated equity beta and a debt beta of 0.15 . The post-buyout asset beta is assumed to equal the pre-asset beta. Using the pre-asset beta and assuming a debt beta of .40 , the hypothetical post-buyout equity is calculated assuming that total debt is equal to $75 \%$ of value of outside stock at announcement buyout premium plus long term debt prior to the buyout and that the equity is equal to the value of total outstanding stock at announcement buyout premium minus total debt.

j Implied equity volatility at $75 \%$ debt financing = implied equity volatility before buyout $x$ [ (Value of total outstanding stock at announcement buyout premium) / ((Value of outside stock at announcement buyout premium $)-(75 \%$ of debt financed $\mathrm{x}$ value of outside stock purchased at announcement buyout premium)) $]^{2}$.

k The increase in equity ( $75 \%$ debt financing assumed) is calculated as the difference in $51 \%$ of the hypothetical post-buyout equity and the dollar value of managers shares at the time of the buyout is number of shares times market price one month before buyout times $1+$ the announcement buyout premium.

I also report the results of calculations of changes in managers' risk and equity investment assuming that all firms in the sample using a financing mix typical of most MBOs. These results are only reported to demonstrate the potential magnitude in the change in managers' risk and how these are related to the amount to be financed, but are not used in further tests because of their conjectural nature.

Kaplan (1989) reports that the post buyout book value of total debt as a percentage of total capital at the time of the buyout on average is $88 \%$ and Cotter and Peck (2001) find that the ratio of total debt to total assets in management controlled LBOs averages $71 \%$. I calculate a hypothetical leverage ratio in the post-buyout firm on the assumption that the purchase of the outstanding stock is $75 \%$ debt financed. To create the ratio, I divide $75 \%$ of the value of outside stock purchased at the initial announcement buyout premium by total firm value, valued at the initial buyout announcement. Table 4, Panel C, shows that the hypothetical leverage in an MBO is $66.34 \%$ (median value $=72.10 \%$ ) when management takes anti-takeover actions versus $59.05 \%$ (median value $=68.49 \%$ ) when management does not. The difference is statistically significant at the $5 \%$ level $(10 \%$ level for differences in medians). This finding is consistent with those of Kaplan and Stein (1993) who reports that MBO leverage tends to increase with the size of the buyout. Thus it is likely that since firms that adopt anti-takeover measures are larger, they would also be more highly leveraged. In contrast, Panel B, also shows that there is no statistically significant difference between the leverage of the two types of firms prior to the buyout.

The increase in leverage increases the risks to managers participating in the MBO by increasing the beta of their equity investment. Table 4, Panel C, reports the hypothetical post-buyout equity beta assuming that the MBO would be $75 \%$ financed with risky debt, as would be the case in a highly leveraged transaction. However, as the debt becomes riskier, the increase in equity risk will be less for a given increase in leverage. I assume that the debt has a 
beta of 0.40, the average value found by Kaplan and Stein (1990) for leveraged recapitalizations. Since these recapitalizations continue to have publicly traded equity after the transaction (unlike buyouts) they can measure the beta on the equity and compute the implicit beta on the debt. The time period of the Kaplan and Stein (1990) study is comparable to mine and the levels of post-transaction debt in that study are comparable to that for MBOs of that period. I can assume then that managers proposing an MBO would likely estimate that the debt they use to finance a MBO would have comparable risk. For these transactions, Kaplan and Stein found that debt was $81 \%$ of total capital. Since this number is more than the $75 \%$ value I assume, using their debt beta of 0.40 will overstate the debt beta and thus understate the increase in the equity beta from increased leverage.

Table 4, Panel C, shows that firms where the managers adopt anti-takeover measures have a statistically significantly greater equity beta at the $10 \%$ level compared to other firms. Table 4 , Panel $\mathrm{B}$, shows that there is no statistically significant difference between the equity beta of the two groups of firms' before their MBO. The difference, however, becomes magnified after the buyout when both sets of firms dramatically increase their leverage by financing the buyout with the same percentage of debt. The results also show that that the average beta for firms that take anti-takeover actions more than doubles.

I also measure equity risk using the volatility of the implied annual stock return. This is a better measure of the risk to the equity investment of managers because they are unlikely to have a fully diversified portfolio. Following Yermack (1995), the pre-buyout volatility of annual stock return is estimated as the square root of the sample variance of daily logarithmic stock returns during the last 200 daily returns 120 days prior to the initial buyout announcement, multiplied by 254 , the number of trading days in a typical year. Since the pre-buyout level of leverage is on average less than $1 \%$, I assume that this is equivalent to the annual stock return volatility of an all equity firm. I then calculate the increase in this volatility created by the increase in leverage by assuming that managers purchase all of the outstanding shares at the buyout premium by borrowing $75 \%$ at the risk free rate ${ }^{4}$ and making an equity investment for the remainder. Total post-buyout firm value is assumed equal to value of total outstanding stock at announcement buyout premium. To determine the leveraged stock volatility, I divide the pre-buyout/ unleveraged annual stock return volatility by a proxy for (Firm Value / Equity Value) ${ }^{2}$; [(value of total outstanding stock at announcement buyout premium) / ((value of total outstanding stock at announcement buyout premium) $-(.75 \mathrm{x}$ value of outsider's stock purchased at announcement buyout premium)) $]^{2}$. This calculation assumes that the inherent risk of the firm does not change as a result of the buyout transaction.

Table 4, Panel C, shows that the volatility of the post-buyout leveraged stock is statistically significantly higher at the $5 \%$ level for firms where management takes anti-takeover actions. In contrast, there is no statistically significant difference in stock volatility prior to the buyout between the firms using anti-takeover measures and those that do not. Panel $\mathrm{C}$, also shows that the average equity volatility for firms that take anti-takeover actions that finance with $75 \%$ debt is more than 100 times the pre-buyout equity volatility, demonstrating that the increase in risk to the managers in an $\mathrm{MBO}$ is not economically insignificant.

To confirm that managers of the two groups of firms face the same risks from operations of the firm prior to the buyout, I report as a third measure of the risk to managers from the buyout: the standard deviation of the growth rate in operating margins (EBITDA/sales) (Kaplan and Stein, 1993). Table 4, Panel B, shows that there is no statistically significantly difference in this measure of risk between the two groups of firms, a finding consistent with the use of the equity beta and the implied annual stock volatility as measures of pre-buyout risk. Thus differences in the risks managers face in the two sets of firms is likely to be driven primarily by the amount of financing needed to complete the MBO.

Finally, Table 4, Panel C, also reports an estimate of the minimum additional amount of equity managers must invest in the firm to retain control. Managers can lose control of the firm if third party investors, i.e., buyout firms, own the majority of the voting equity in the MBO. Loss of voting control would create additional risks for managers, i.e., the buyout specialist could potentially vote them out of a job. Since Cotter and Peck (2001) show that most often post-buyout equity is common stock with one vote for each share, I assume that managers must own at least $51 \%$ of this equity to retain control. Table 4 , Panel C, shows that the increase in managers' equity investment must be significantly higher for firms where managers have taken anti-takeover actions than those that 
haven't. Thus for firms that take such actions, not only will managers face greater leverage and a higher equity beta and volatility, but they will also have to invest more equity in the firm to retain control.

Of course, the managers of each firm will pick a financing mix that minimizes the managers' risk and thus will not all will choose to borrow $75 \%$ of the amount needed. But as the results in Table 4 demonstrate, as the amount that needs to be financed to complete the MBO increases, risk to the managers increases whether the MBO is financed with debt or equity, because they either have to borrow more or invest more. If the managers borrow more for the additional financing required, they increase the risk, i.e., beta and volatility, of their equity investment. If the managers invest more of their own money for the additional financing, they increase the diversifiable risk in their personal portfolios. Since the plans of the managers to finance the buyout transaction and changes in risk to their personal wealth cannot be observed at the time of their offer, I use the dollar amount of shares not beneficially owned by management that must be purchased at the initial buyout announcement premium as a proxy for the increase in the risk to managers in all further tests.

\subsection{Other Confounding Variables}

In this section, I examine other variables that are likely to be both related to management's decision to take anti-takeover actions and correlated with the amount to be financed. I include these variables to rule out that the observed positive relation between managers' use of anti-takeover measures and the amount to be financed is because this amount acts as a proxy for one of these other variables rather than as a proxy for the potential risks managers' face in the MBO created by the financing needed to complete the transaction. Because I only have a proxy for the managers' risks and not a direct measure of the risks themselves, there is a greater burden to rule out alternative explanations. Thus I examine several other variables.

\subsubsection{Firm Size And Pre-Buyout Managerial Shareholdings}

The size of the firm's market equity value is likely to be highly correlated with the amount of outside stock that must be purchased by management. If larger firms receive more takeover bids because they are more visible or have greater break up value, then the positive relation between the amount of outside stock that must be purchased and management's decision to take anti-takeover actions may be driven by size. Table 5, Panel A, reports the market value of the equity one month prior to the initial buyout announcement. On average the market value of the equity is $\$ 386.022$ million (median value $=\$ 173.915$ million) for firms where management deters a takeover versus $\$ 257.168$ million (median value $=\$ 113.180$ million) for firms where management does not. The medians are statistically significantly different at the $10 \%$ level. I control for size in all subsequent tests.

Another variable that is likely to be highly (negatively) correlated with the amount of outside shares mangers must purchase to complete is the percentage of shares held by management. In my sample, the Spearmann rank correlation coefficient between these two variables is 0.37620 and is statistically significant at the $1 \%$ level. The relation between the amount of outside shares that management must purchase and their decision to take antitakeover actions may be driven by the percentage of shares held by the managers. Furthermore, as managers' stock ownership increases, they have a natural defense against a takeover attempt (see Stulz, 1988; and Song and Walking, 1993). Managers who are significant owners then are likely to have less need to take anti-takeover actions. Table 5, Panel A, shows that the managers own a statistically significantly lower percentage of the shares in the firms where managers act to deter a takeover. Thus I control for the percentage of shares held by managers in subsequent tests.

\subsubsection{CEO Compensation And Gains To A Takeover}

I also investigate whether the wealth gains from a successful takeover influence management's decision to take adopt anti-takeover measures. Following Cotter and Zenner (1994), I measure the net present value (NPV) of the takeover to the chief executive officer as the capital gain on the CEO's shares plus the PV of "golden parachute payments" minus the PV of the lost cash compensation on the assumption that the CEO would not be retained. I also include the stock options held by the CEO because option ownership can make increasing equity risk in the MBO more attractive. Since options are more valuable when the volatility of the stock increases, I use the implied annual volatility 
as an adjustment to the value of the options. I also investigate whether total cash compensation may play a role in the decision to adopt anti-takeover measures. Table 5, Panel B, shows that none of these variables is significantly different between firms where management adopts anti-takeover measures and other firms.

\subsubsection{Outside Blockholders}

Outside blockholders can also influence managers' decisions to adopt anti-takeover measures. Outside blockholders can facilitate takeovers by either aligning with or voting against management in a takeover contest, (see Walking, 1985; Edminster and Walking, 1985; Shleifer and Vishny, 1986; and Peck, 1996). This is particularly so when takeover measures require a shareholder vote (see Brickley, Lease and Smith, 1988; and Argawal and Mandelker, 1990). Peck (1996) also shows that buyout contests attract new outside blockholders so I include the frequency of block acquisitions either in the year before or during the contest. Table 5, Panel C, shows that firms where management adopt anti-takeover measures are significantly more likely to have an outside block acquisition. Because the presence of outside blocks can be correlated with the amount of outside shares that management must purchase, I control for both the acquisition of an outside block and the size of outside blockholdings in subsequent tests.

\subsubsection{Board Composition}

Previous researchers have shown that the composition of the board effects the stock price reaction associated with anti-takeover actions (Brickley, Coles, and Terry, 1994; and McWilliams and Sen, 1997) and the outcome of the takeover contest (Byrd, and Hickman, 1992; and Cotter, Shivdasani, and Zenner, 1997). In an MBO, if managers control the board, an outside offer is more likely to be rejected. Thus I include a dummy variable to indicate whether management controls the board by virtue of having more than half of the board seats.

\subsubsection{Firm Performance}

I also investigate whether there are differences in the performance of the firm that is the buyout target. Above average performance means managers are more likely to earn a higher return for the risk they bear in taking the firm private. Following, Kaplan (1989) and Cotter and Peck (2001), I use operating margins, (EBITDA/ total sales), as a measure of firm performance. Table 5, Panel E, shows that firm performance is not statistically significantly different between the two groups of firms.

\subsubsection{Initial Buyout Offer}

The findings of previous researchers (see Walking, 1985; Hirshleifer and Png, 1989; and Jennings and Mazzeo, 1993) suggest that if the initial buyout offer is high enough, competitive bidders are likely to be discouraged and management is less likely to need to adopt anti-takeover measures. Table 5, Panel F, shows there is no statistically significant difference in the initial buyout premium.

\subsubsection{Outside Bids}

The relation between the number of outside bids and decision by managers to adopt anti-takeover measures is ambiguous. On the one hand, management is more likely to take actions to deter a takeover in response to or in anticipation of a takeover threat. On the other hand, management may take pre-emptive actions to deter a takeover threat and thereby reduce the number of competitive bidders. Furthermore, managers' decision to adopt an antitakeover measure may act as a signal that the buyout warrants a higher premium and thus may increase the amount of competitive bidding (see Jennings and Mazzeo, 1993).

Table 5, Panel F, shows that the number of competing bids is higher when managers adopt an anti-takeover measure. The number of competitive bids includes both initial bids and revisions in existing bids. The average number of competitive bids is 1.48 (median value $=1$ ) for firms where management adopts an anti-takeover measure and 0.56 (median value $=0$ ) for firms where management does not. Both the average and median values are statistically significantly different at the $1 \%$ level. Table 5 , Panel F, also shows that managers are more likely to 
adopt anti-takeover measures when an outsider has initiated the buyout. These results confirm the findings of previous researchers that managers are more likely to adopt anti-takeover measures when there is a higher probability of a takeover threat.

Table 5: Differences In Firm Characteristics For Firms That Do And Do Not Adopt Anti-Takeover Measures (Medians Reported In Parenthesis) ${ }^{a}$

\begin{tabular}{|c|c|c|}
\hline Firm characteristics & $\begin{array}{l}\text { Firms that have adopted } \\
\text { anti-takeover measures } \\
(\mathrm{n}=33)\end{array}$ & $\begin{array}{c}\text { Firms that have not adopted } \\
\text { anti-takeover measures } \\
(\mathrm{n}=78)\end{array}$ \\
\hline \multicolumn{3}{|l|}{ Panel A: Firm Size and Pre-buyout Managerial Shareholdings } \\
\hline $\begin{array}{l}\text { Market value of equity }{ }^{b} \\
\text { (millions) }\end{array}$ & $\begin{array}{c}\$ 386.02 \\
(\$ 173.92)\end{array}$ & $\begin{array}{c}257.17 \\
(113.18)^{*}\end{array}$ \\
\hline Percentage of stock held by management ${ }^{c}$ & $\begin{array}{l}10.42 \% \\
(3.77 \%) \\
\end{array}$ & $\begin{array}{l}19.58 \% * * \\
(8.12 \%)^{* *}\end{array}$ \\
\hline \multicolumn{3}{|l|}{ Panel B: CEO Compensation and Gains to a Takeover } \\
\hline $\begin{array}{l}\text { NPV of takeover for } \mathrm{CEO}^{\mathrm{d}} \\
\text { (millions) }\end{array}$ & $\begin{array}{c}\$ 3.52 \\
(\$ 2.51)\end{array}$ & $\begin{array}{c}2.67 \\
(2.12)\end{array}$ \\
\hline $\begin{array}{l}\text { Percentage of number of options awarded to number of shares held } \\
\text { by CEO in the year prior to the buyout anouncement }\end{array}$ & $\begin{array}{l}7.26 \% \\
(0.00)\end{array}$ & $\begin{array}{c}37.56 \% \\
(0.00)\end{array}$ \\
\hline $\begin{array}{l}\text { Percentage of number of options awarded to number of shares held by } \\
\text { CEO in the year after the buyout announcement }\end{array}$ & $\begin{array}{l}11.72 \% \\
(0.00) \\
(\mathrm{n}=10)\end{array}$ & $\begin{array}{l}31.14 \\
(0.00) \\
(\mathrm{n}=12)\end{array}$ \\
\hline $\begin{array}{l}\text { Implied annual volatility * }(1-\% \text { of number of options awarded to \# } \\
\text { of shares held by CEO in year prior to buyout announcement })\end{array}$ & $\begin{array}{c}185.58 \\
(177.65)\end{array}$ & $\begin{array}{c}117.14 \\
(172.17)\end{array}$ \\
\hline $\begin{array}{l}\text { Total cash compensation for } \mathrm{CEO} / \text { total sales for the year before the } \\
\text { buyout }{ }^{\mathrm{e}}\end{array}$ & $\begin{array}{c}0.0013 \\
(0.0008) \\
(\mathrm{n}=26)\end{array}$ & $\begin{array}{c}0.0111 \\
(0.0010) \\
(n=63)\end{array}$ \\
\hline \multicolumn{3}{|l|}{ Panel C: Outside Blockholders } \\
\hline Number of firms with an outside block acquisition & $\begin{array}{c}21 \\
(63.64 \%)\end{array}$ & $\begin{array}{c}34 \\
(43.59 \%) * *\end{array}$ \\
\hline Percentage of stock held by $5 \%$ outsiders $^{c}$ & $\begin{array}{c}5.20 \% \\
(0.00 \%) \\
\end{array}$ & $\begin{array}{c}5.03 \% \\
(0.00 \%) \\
\end{array}$ \\
\hline \multicolumn{3}{|l|}{ Panel D: Board Composition } \\
\hline Number of firms where management controls the board ${ }^{f}$ & $\begin{array}{c}3 \\
(9.09 \%)\end{array}$ & $\begin{array}{c}16 \\
(20.51 \%)\end{array}$ \\
\hline \multicolumn{3}{|l|}{ Panel E: Firm performance } \\
\hline EBITDA/sales year before buyout ${ }^{g}$ & $\begin{array}{c}0.11 \\
(0.10) \\
(\mathrm{n}=26) \\
\end{array}$ & $\begin{array}{c}0.09 \\
(0.09) \\
(\mathrm{n}=62) \\
\end{array}$ \\
\hline \multicolumn{3}{|l|}{ Panel F: Bidding Activity and Contest Outcome } \\
\hline Number of firms where outside bidder initiates buyout & $\begin{array}{c}12 \\
(36.36 \%)\end{array}$ & $\begin{array}{c}5^{* *} \\
(6.41 \%)\end{array}$ \\
\hline Announcement buyout premium & $\begin{array}{c}22.55 \% \\
(21.37 \%)\end{array}$ & $\begin{array}{c}20.37 \\
(20.57)\end{array}$ \\
\hline Average number of outside bids & $\begin{array}{l}1.48 \\
(1)\end{array}$ & $\begin{array}{c}0.56^{* * *} \\
(0)^{* * *}\end{array}$ \\
\hline Average number of revisions in management's bid & $\begin{array}{c}1.03 \\
(1)\end{array}$ & $\begin{array}{c}0.71 \\
(0)\end{array}$ \\
\hline Final buyout premium ${ }^{\mathrm{h}}$ & $\begin{array}{c}34.26 \% \\
(35.17 \%)\end{array}$ & $\begin{array}{l}5.94 * * \\
(17.41)\end{array}$ \\
\hline Percentage change in final offer from initial buyout price ${ }^{\mathrm{i}}$ & $\begin{array}{c}25.80 \% \\
(16.89 \%)\end{array}$ & $\begin{array}{c}6.73 * * * \\
(7.34)^{* * *}\end{array}$ \\
\hline Number of firms where buyout fails & $\begin{array}{c}2 \\
(6.06 \%)\end{array}$ & $\begin{array}{c}10 \\
(12.82 \%)\end{array}$ \\
\hline Number of firms where management buyout is successful & $\begin{array}{c}21 \\
(63.69 \%)\end{array}$ & $\begin{array}{c}52 \\
(66.67 \%)\end{array}$ \\
\hline
\end{tabular}


a For explanatory notes, see Table 1 and 4, except where noted.

b Firm size is measured as market value of equity one month prior to the $\mathrm{MBO}$ announcement.

c Data on management holdings and 5\% outside blockholders is collected from the first proxy statement during the year before the MBO offer announcement date.

d The NPV of the takeover to the CEO is calculated following Cotter and Zenner (1994). The NPV is calculated as the capital gain on the CEO's shares plus the PV of golden parachute payments minus the PV of lost cash compensation. The PV of lost cash compensation is the PV of the CEO's total cash compensation provided in the last proxy statement available before the MBO offer announcement. The number of years is based on the difference between the CEO's age and 65. If the difference is less than three or more than 15 years, 3 and 15 years is used, respectively, for the lost compensation calculation. The NPV of golden parachute payments is based on the amount and years provided in the last proxy statement available for the MBO offer announcement. Both NPV calculations use a discount rate of $3 \%$. The capital gain on the CEO's shares is based on the number of shares plus options exercisable within 6 months provided in the last proxy statement before the MBO offer announcement. The capital gain is calculated using the announcement buyout premium.

e Total cash compensation for the CEO is taken from either the proxy statement or 10-K for the first full fiscal year before (after) the buyout. Total sales is Compustat item \#12 and is for the first full fiscal year before (after) the buyout.

f Data on board composition is collected from the first proxy statement during the year before the MBO offer announcement date. The board is defined as management controlled if management has more than $50 \%$ of the board seats.

$\mathrm{g}$ (EBITDA/ total sales) before the buyout is measured for the first full fiscal year before the buyout completion; after the buyout (EBITDA/total sales) is measured for the first full fiscal year after the buyout completion.

h The final buyout premium is the cumulative abnormal return from one month prior to the initial buyout announcement until the date of completion or two years in the case of failed buyouts.

i The initial offer price is the average stock market price on day $-1,0,+1$. Day 0 is the day the initial buyout offer was announced in the Wall Street Journal or came over the Dow Jones News Wire. The final offer price is the stock market price on the date of completion of the buyout or two years in the case of failed buyouts. The percentage change in price is calculated as the percentage change between these two prices.

Table 6: Likelihood Of Management Adopting An Anti-Takeover Measure (p-Values Reported In Parenthesis) ${ }^{a}$

\begin{tabular}{lcc}
\hline \multicolumn{1}{c}{ Independent variables } & $\begin{array}{c}\text { Spearman rank } \\
\text { correlation coefficients }\end{array}$ & $\begin{array}{c}\text { Coefficient estimates from a logit } \\
\text { regression of a dummy variable for } \\
\text { management adopting an anti-takeover } \\
\text { measure on independent variables }\end{array}$ \\
\hline Intercept & --- & $-3.1789^{* *}$ \\
& $(0.0262)$ \\
\hline Value of outside stock purchased at & $0.18208^{*}$ & $9.418 \times 10^{-9 *}$ \\
announcement buyout premium & $(0.0558)$ & $(0.0599)$ \\
\hline Implied annual volatility ${ }^{*}(1-$ percentage of & 0.06269 & 0.00266 \\
options held to number of shares held by CEO) & $(0.5253)$ & $(0.7103)$ \\
\hline Beta & 0.12918 & 0.9639 \\
& $(0.1766)$ & $(0.2385)$ \\
\hline NPV of takeover for CEO & 0.12744 & $1.544 \times 10^{-9}$ \\
& $(0.1951)$ & $(0.9913)$ \\
\hline Total number of outside bids & $0.42130^{* * *}$ & $0.8325^{* * *}$ \\
\hline Outside block acquisition & $(0.001)$ & $(0.0067)$ \\
\hline Announcement buyout premium & $0.18784 * *$ & 0.1151 \\
& $(0.0473)$ & $(0.8649)$ \\
\hline Number of firms where management controls the & 0.06698 & -2.0512 \\
board & $(0.4829)$ & $(0.4354)$ \\
\hline Percentage of stock held by management & -0.13860 & -1.5171 \\
& $(0.1468)$ & $(0.1502)$ \\
\hline Percentage of stock held by 5\% outsiders & $-0.20324 * *$ & 0.8316 \\
& $(0.0316)$ & $(0.6197)$ \\
\hline Firm size & -0.02047 & 3.77771 \\
& $(0.8312)$ & $(0.3408)$ \\
\hline EBITDA/sales) year before buyout & $0.15932 *$ & $-0.00001^{*}$ \\
\hline p-value for significance of entire regression & $(0.0949)$ & $(0.0766)$ \\
\hline
\end{tabular}

a For explanatory notes, see Tables 1,4 , and 5. 


\subsection{The Likelihood That Management Adopts An Anti-Takeover Measure}

Table 6 reports the relation between the likelihood that management adopts an anti-takeover measure and various explanatory variables. The results from a logit regression shows that managers are more likely to adopt an anti-takeover device when managers' risk in the MBO increases as measured by the value of outside shares that must be purchased at the initial buyout premium. This result is statistically significant and continues to hold when I control for other variables discussed above. Most notable, including size and the percentage of shares held by managers in the regression does not change the statistical significance of the coefficient on the value of outside shares to be purchased as a proxy for the financing risks in the proposed MBO. The results in Table 6 also show that managers are more likely to adopt an anti-takeover measure when there is more competitive bidding and when the size of their firm is larger. This result is consistent with that of other researchers that find that managers are more likely to adopt anti-takeover measures when there is a higher probability of a takeover threat (see Comment and Schwert, 1995).

\section{Changes In Bidding After Anti-Takeover Measures Are Adopted}

\subsection{Changes In Outside Bids}

Firms with more competitive bids are more likely to take anti-takeover actions as Tables 6 and 5 show. The majority of this competitive bidding occur after management has adopted an anti-takeover measure. For the 33 firms with anti-takeover measures, the average number of competitive bids before these measures are adopted is 0.3939 (median value $=0$ ), which increases to 0.8788 (median value $=1$ ) after these measures are adopted. The difference in the average values is statistically significant at the $5 \%$ level; the difference in the median values is statistically significant at the $1 \%$ level.

The increase in outside bids after the managers take anti-takeover actions can occur for two reasons. First, these actions may serve as a signal to outsiders that the managers are willing to negotiate the exchange of control of the firm for a higher price or that management's offer is low. Second, the managers may decide to take anti-takeover actions when a takeover offer is already eminent, but their actions fail to discourage the offer.

To discriminate between these two hypotheses, I attempt to control for all other variables that may affect the likelihood of higher outside bid than management's initial offer. These variables include, whether the buyout was management initiated, the total number of revisions in management's bid, the acquisition of an outside block, the announcement of the buyout premium, the control by the managers of the board, the percentage of stock held by management, the percentage of stock held by outsiders that own a $5 \%$ block or more, and the size of the firm. I also distinguish between anti-takeover actions taken after the contest has begun and those taken before. Table 7 reports the results of a logistic regression of the likelihood of a higher outside offer after management's initial offer. The table shows that a higher offer is statistically significantly positively related to anti-takeover actions taken after the buyout contest has begun and after controlling for other variables that are likely to be related to a higher offer. These results suggest that anti-takeover actions taken after the contest begins are more often used to elicit a higher offer from a competitive bidder than to protect management's offer.

\subsection{Changes In Management's Bid}

I also investigate managers' bidding behavior in relation to the use of anti-takeover measures. If managers are able to use such measures in an attempt to acquire the firm cheaply, they are less likely to revise their initial bid upwards after adopting an anti-takeover device. For the 33 firms with takeover deterrence, the average number of revisions in management's bid before deterrence is 0.32121 (median value $=0$ ), and an average value of 0.3939 (median value $=0$ ) afterwards. This difference is not statistically significant. Table 5, panel F, also shows that the average and ${ }_{r}$ median number of revisions in the managers' bid is not statistically significantly different between firms where the managers take anti-takeover actions and firms where they do not. These results indicate that managers are not able to effectively use anti-takeover devices to protect a low offer. 
Table 7: Likelihood Of A Higher Outside Offer After Management's Initial Offer (P-Values Reported In Parenthesis) ${ }^{a}$

\begin{tabular}{lcc}
\hline \multicolumn{1}{c}{ Independent variables ${ }^{\mathbf{b}}$} & $\begin{array}{c}\text { Spearman rank } \\
\text { correlation coefficients }\end{array}$ & $\begin{array}{c}\text { Coefficient estimates fróm a logit } \\
\text { regression of a dummy variable for a } \\
\text { higher offer on independent variables }\end{array}$ \\
\hline Intercept & $---2.0123^{* *}$ & $(0.0396)$ \\
\hline Number of anti-takeover measures adopted & 0.05881 & 0.1563 \\
before initial buyout offer & $(0.5398)$ & $(0.7884)$ \\
\hline Number of anti-takeover measures adopted after & $0.18748^{* *}$ & $1.17708^{*}$ \\
initial buyout offer & $(0.0488)$ & $(0.0834)$ \\
\hline Buyout is management initiated & -0.08919 & 1.3508 \\
& $(0.3519)$ & $(0.1124)$ \\
\hline Total number of revisions in management's bid & $-0.22798^{* *}$ & $-0.9696^{* * *}$ \\
& $(0.0161)$ & $(0.0103)$ \\
\hline Outside block acquisition & $0.27742^{* * *}$ & $1.6153^{* * *}$ \\
& $(0.0032)$ & $(0.0026)$ \\
\hline Announcement buyout premium & 0.01749 & 0.6682 \\
& $(0.8555)$ & $(0.6868)$ \\
\hline Management has control of the board & $-0.19912^{* *}$ & -1.0289 \\
& $(0.0362)$ & $(0.1587)$ \\
\hline Percentage of stock held by management & -0.14098 & -1.1556 \\
& $(0.1400)$ & $(0.3301)$ \\
\hline Percentage of stock held by 5\% outsiders & -0.13634 & 1.0699 \\
& $(0.1536)$ & $(0.6962)$ \\
\hline Firm size & 0.01282 & $-6.76 \times 10^{-7}$ \\
& $(0.8938)$ & $(0.3102)$ \\
\hline p-value for significance of entire regression & --- & $0.01{ }^{* * *}$ \\
& & $(\mathrm{n}=111)$ \\
\hline
\end{tabular}

a For explanatory notes, see Tables 1,4 , and 5, except where noted.

b Incidence of various events are measured prior to the higher offer.

\section{Anti-Takeover Actions And The Buyout Outcome}

If managers are using anti-takeover measures as a device to acquire the firm at a low price, then such measures will be associated with a higher likelihood of the MBO's success, a smaller change in the initial offer price, and a lower ultimate buyout premium. Table 5, Panel F, shows that the proportion of successful MBOs is not higher for those MBOs in which the managers adopt anti-takeover measures. Table 5, Panel F, also shows that the percentage change in the initial offer price and the final buyout premium is higher for firms where management adopts anti-takeover measures than those firms where management does not. These results are statistically significant at the $1 \%$ and $5 \%$ level respectively.

I further examine whether the higher percentage change in price occurs because managers are able to use anti-takeover measures to negotiate a higher price that is ultimately offered by an outside bidder. Table 8 reports the results of a regression of the percentage change in the initial price on dummy variables that reflect whether management has adopted an anti-takeover device and whether management or an outside bidder has successfully won the buyout contest. I also include the following control variables in the regression: whether there is an outside block acquisition, number of outside bids, revisions in management's bid, initial buyout price, whether management controls the board, percentage of stock held by management, percentage of stock held by $5 \%$ outsiders, and firm size.

The coefficient on the takeover dummy and the MBO dummy are both positive and statistically significant reflecting that, on average, regardless of who wins the firm, the final buyout price is higher than the initial offer. ${ }^{5}$ More importantly, the dummy variable that is equal to one when there is a takeover and anti-takeover measures have 
adopted is positive and statistically significant. This indicates that the change in price when there is a takeover is even higher when management has adopted an anti-takeover device. This result is consistent with the hypothesis that managers use of anti-takeover measures as a negotiating tool. In contrast, if managers were able to use these measures to protect a low offer, then the dummy variable that is equal to one when the MBO is successful and antitakeover measures have been adopted would be negative, indicating that managers are not compelled to raise the price of their initial offer. Table 8 shows that the coefficient for this variable is positive but not statistically significant. This result is inconsistent with the hypothesis that managers use anti-takeover devices to protect a low offer.

Table 8: Percentage Change In Final Offer From Initial Buyout Price (p-Values Reported In Parenthesis) ${ }^{\text {a }}$

\begin{tabular}{lcc}
\hline \multicolumn{1}{c}{ Independent variables } & $\begin{array}{c}\text { Spearman rank correlation } \\
\text { coefficients }\end{array}$ & $\begin{array}{c}\text { Coefficient estimates from } \\
\text { regression of percentage change } \\
\text { in final offer from initial buyout } \\
\text { price on independent variables }\end{array}$ \\
\hline Intercept & --- & -12.0011126 \\
\hline Anti-takeover measure adopted and successful & $0.34300^{* * *}$ & $(0.1820)$ \\
takeover & $(0.0004)$ & $24.632176^{* *}$ \\
Anti-takeover measure adopted and successful & 0.03525 & $(0.0496)$ \\
MBO & $(0.7237)$ & 3.389696 \\
\hline Successful takeover & $0.23993^{* * *}$ & $(0.6774)$ \\
\hline Successful MBO & $(0.0146)$ & $24.622128^{* *}$ \\
& 0.04628 & $0.0281)$ \\
\hline Outside block acquisition & $(0.6425)$ & $22.076160^{* * *}$ \\
\hline Total number of outside bids & 0.11429 & $(0.0134)$ \\
\hline Total number of revisions in management's bid & $(0.2503)$ & 3.354435 \\
& $0.26199^{* * *}$ & $(0.5740)$ \\
\hline Initial buyout price & $(0.0075)$ & -1.672619 \\
& $0.27920^{* * *}$ & $(0.4233)$ \\
\hline Number of firms where management controls the & $(0.0043)$ & $5.661640^{* *}$ \\
board & -0.13421 & $(0.0465)$ \\
\hline Percentage of stock held by management & $(0.1765)$ & 0.001603 \\
& -0.12931 & $(0.8383)$ \\
\hline Percentage of stock held by $5 \%$ outsiders & $(0.1930)$ & -2.788674 \\
& -0.10780 & $(0.7210)$ \\
\hline Firm size & $(0.2784)$ & 1.391918 \\
\hline p-value for significance of entire regression & -0.10548 & $(0.8997)$ \\
\hline
\end{tabular}

a For explanatory notes, see Tables 1,4 , and 5, except where noted.

\section{Conclusion}

In a sample of MBO attempts, I find that about a third of the time mangers adopt anti-takeover measures. My results support the hypothesis that managers use anti-takeover measures to negotiate for a higher price when the offer they must meet is no longer low enough to compensate them for their risks in the MBO. The evidence does not support the hypothesis that managers can use such measures to protect a low offer. 
These findings suggest that changes in the risks borne by managers as well as changes in their wealth are motives to take anti-takeover actions. They also support the fundamental insight of early researchers (see Jensen and Meckling, 1976; Holstrom, 1979; and Fama, 1980) that managers face different risks than other shareholders and that their unique risk position influences their behavior.

\section{Suggestions For Future Research}

The changes in risks that managers face in buyout contests are primarily driven by changes in the firm's capital structure, i.e., increases in leverage, as the result of financing the transaction. How might managers' risk change in other types of control contests? The conventional wisdom is that takeover attempts occur when management becomes entrenched and firm performance suffers (see Mikkelson and Partch, 1997). There is also evidence that subsequent to a failed takeover attempt the incumbent management team will take steps to improve the performance of the firm by cost cutting, selling-off poorly performing assets, or other changes in operating strategy (see Franks and Mayer, 1996, and Denis and Kruse, 2000). If managers perceive that these changes are likely to create uncompensated risks for them, they are more likely to relinquish control at a higher negotiated price. Furthermore, the components of executive compensation contracts would be important factors in determining how managers react to changes in both the firm's operations as well as control. Thus, future areas of research are both the identification of other components of executive compensation and changes in the firm's overall risk and performance that explain management's behavior in other types of control contests. $\mathbb{D}$

\section{Endnotes}

1. Practical advice for managers contemplating an MBO point out these risks and caution management against over bidding for their firm: " $(\mathrm{t})$ he stakes are high in mounting a management buy-out: get it wrong and you could bankrupt yourself and lose your job" and "(b)eware of buying high." (Garret, A., "How to Launch an MBO," Management Today, London, November 2002, p. 80).

2. Contested MBO offers, however, are not specific to the eighties for the financial press reports that the dollar volume of $\mathrm{MBO}$ transactions have increased and that managers often find themselves outbid for their company (see "Private Dreams," CFO, November 2000, vol. 16, no. 13, pp. 60-68).

3. While, I search for the announcement of all the types of anti-takeover amendments identified by prior researchers (see DeAngelo and Rice, 1983; Linn and McConnell, 1983; Dann and DeAngelo, 1988; Maletesta and Walking, 1988; Ryngaert, 1988; Jarrell and Poulsen, 1987, 1988; Karpoff and Maletesta, 1989; McWilliams, 1990; Brickley, Coles, and Terry, 1994; Comment and Schwert, 1995; and McWilliams and Sen, 1997), these are the only types found in the sample.

4. I assume the debt to be risk free because I cannot observe the volatility of the debt nor does any study report these estimates for HLT transactions. As a check on the robustness of this result, I also recalculate the change in equity volatility assuming the buyout transaction is only $25 \%$ financed with debt. The resulting equity volatility continues to be statistically significantly higher at the $10 \%$ level for firms with anti-takeover actions than those without.

5. In this regression model, the intercept reflects the average market price change in the case of failed buyouts- negative. Table 5, Panel F, shows that the frequency of failed buyouts is not statistically significantly different between firms with anti-takeover actions and those without.

\section{References}

1. Agrawal, A. and G. N. Mandelker, "Large Shareholders and the Monitoring of Managers: The Case of Antitakeover Charter Amendments," Journal of Financial and Quantitative Analysis, Vol. 25, pp. 143-162, 1990.

2. Alexander, J.C., S.W. Barnhart, and M.F. Spivey, "Do firm and state antitakeover provisios affect how well CEOs earn their pay?" Managerial and Decision Economics, Vol. 21, pp. 315-328, 2000.

3. Andrade, G. and S.N. Kaplan, "How costly is financial (not economic) distress? Evidence from highly levered transactions that became distressed," Journal of Finance, Vol. 53, pp. 1443-1493, 1998. 
4. Borokhovich, K. A., K. R. Brunarski, and R. Parrino, "CEO Contracting and Antitakeover Amendments," The Journal of Finance, Vol. LII, pp.1495-1517, 1997.

5. Boyle, G. W., R. B. Carter, and R. P. Storer, "Extraordinary Antitakeover Provisions and Insider Ownership Structure: The case of converting savings and loans," Journal of Finance and Quantitative Analysis, Vol. 33, pp. 291-304, 1998.

6. Brickley, J.A., J. L. Coles, and R. L. Terry, "Outside directors and the adoption of poison pills," The Journal of Financial Economics, Vol. 35, pp. 371-390, 1994.

7. Brickley, J.A., R.C. Lease, and C.W. Smith, Jr., "Ownership structure and voting on antitakeover amendments," Journal of Financial Economics, Vol. 20, pp. 267-291, 1998.

8. Byrd, J. W. and K. A. Hickman, "Do outside directors monitor managers? Evidence from tender offer bids," Journal of Financial Economics, Vol. 32, pp. 195-221, 1992.

9. Comment, R. and G. W. Schwert, "Poison or placebo? Evidence on the deterrence and wealth effects of modern antitakeover measures," Journal of Financial Economics, Vol. 39, pp. 3-43, 1995.

10. Cotter, J. F. and S.W. Peck, "The structure of debt and active equity investors: The case of the buyout specialist," Journal of Financial Economics, Vol. 59, pp. 101-147, 2001.

11. Cotter, J. F., A. Shivdasani, and M. Zenner, "Do independent directors enhance target shareholder wealth during tender offers?" Journal of Financial Economics, Vol. 43, pp.195-218, 1997.

12. Cotter, J.F. and M. Zenner, "How managerial wealth affects the tender offer process," Journal of Financial Economics, Vol. 35, pp. 63-97, 1994.

13. Dann, L. Y. and H. DeAngelo, "Corporate policy and corporate control: A study of defensive adjustments in asset and ownership structure," Journal of Financial Economics, Vol. 20, pp. 87-127, 1988.

14. DeAngelo, H., L. DeAngelo, and E. Rice, "Going Private: Minority Freezeouts and Stockholder Wealth," Journal of Law \& Economics, Vol. XXVII, pp. 367-401, 1984.

15. DeAngelo, H. and E. Rice, "Antitakeover charter amendments and stockholder wealth," Journal of Financial Economics, Vol. 11, pp. 29-359, 1983.

16. Denis, D. J. and T. A. Kruse, "Managerial discipline and corporate restructuring following performance declines," Journal of Financial Economics, Vol. 55, pp.391-424, 2000.

17. Edminster, R. O. and R. A. Walking, "Determinants of tender offer premiums," Financial Analysts Journal, Vol. January-February, pp. 27-37, 1985.

18. Fama, E. F., "Agency Problems and the Theory of the Firm," Journal of Political Economy, Vol. 88, pp. 288-298, 1980.

19. Franks, J. and C. Mayer. "Hostile takeovers and the correction of managerial failure." Journal of Financial Economics, Vol. 40, pp.163-181, 1996.

20. Hirshleifer, D. and I.P.L. Png, "Facilitation of Competing Bids and the Price of a Takeover Target," The Review of Financial Studies, Vol. 2, pp. 587-606, 1989.

21. Holmstrom, B., "Moral Hazard and Observability," Bell Journal of Economics, Vol. 10, pp. 74-91, 1979.

22. Jarrell, G. A. and A. B. Poulsen, "Shark Repellents and Stock Prices Since 1980," Journal of Financial Economics, Vol. 19, pp. 127-169, 1987.

23. Jarrell, G. A. and A. B. Poulsen, "Dual-Class Recapitalizations as Anti-takeover Mechanisms: The Recent Evidence," Journal of Financial Economics, Vol. 20, pp. 129-153, 1988.

24. Jennings, R. H. and M. A. Mazzeo, "Competing bids, target management resistance, and the structure of takeover bids," The Review of Financial Studies, Vol. 6, pp. 883-909, 1993.

25. Jensen, M. C., "Agency costs of free cash flow, corporate finance, and takeovers," American Economic Review, Vol. 76, pp. 323-329, 1986.

26. Jensen, M. C., "The eclipse of the public corporation," Harvard Business Review, Vol. 89, pp. 61-74, 1989.

27. Jensen, M. C. and W. H. Meckling, "Theory of the Firm: Managerial Behavior, Agency Costs and Ownership Structure,” Journal of Financial Economics, Vol. 3, pp. 305-360, 1976.

28. Kaplan, S. N., "The effects of management buyouts on operating performance and value," Journal of Financial Economics, Vol. 24, pp. 217-254, 1989.

29. Kaplan, S.N. and J.C. Stein, "How risky is the debt in highly leveraged transactions?" The Journal of Financial Economics, Vol. 27, pp. 215-245, 1990.

30. Kaplan, S. N., and J.C. Stein, "The evolution of buyout pricing and financial structure in the 1980s," The Quarterly Journal of Economics, Vol. CVIII, pp. 313-358, 1993. 
31. Karpoff, J.M. and P.H. Maletesta, "The Wealth Effects of Second Generation State Takeover Legislation," Journal of Financial Economics, Vol. 25, pp. 291-323, 1989.

32. Knoeber, C., "Golden parachutes, sharek repellents and hostile tender offers," American Economic Review, Vol. 77, pp. 155-167, 1986.

33. Lee. D.S., "Management buyout proposals and inside information," The Journal of Finance, Vol. 47, pp. 1061-1079, 1992.

34. Lehn, K. and A. Poulsen, "Free cash flow and stockholder gains in going private transactions," The Journal of Finance, Vol. 44, pp. 771-788, 1989.

35. Linn, S.and J. J. McConnell, "An empirical investigation of the impact of antitakeover' amendments on common stock prices," Journal of Financial Economics, Vol.11, pp. 361-399, 1983.

36. Lowenstein, L., "Management buyouts," Columbia Law Review, Vol. 85, pp. 730-784, 1985.

37. Malezadeh, A. R., V.B. McWilliams, and N. Sen, "Implications of CEO Structural and Ownership Powers, Board Ownership and Composition on the Market's Reaction to Antitakeover Charter Amendments," The Journal of Applied Business Research, Vol. 14, pp. 53-62, 1998.

38. McWilliams, V. B., "Managerial Share Ownership and the Stock Price Effects of Antitakeover Amendment Proposals," The Journal of Finance, Vol. XLV, pp.1627-1640, 1990.

39. McWilliams, V. B. and N. Sen, "Board Monitoring and Antitakeover Amendments," Journal of Financial and Quantitative Analysis, Vol. 32, pp. 491-505, 1997.

40. Malatesta, P. H. and R. Walking, "Poison pill securities: Stockholder wealth, profitability, and ownership structure," Journal of Financial Economics, Vol. 20, pp. 347-376, 1988.

41. Mikkelson, W. H. and M.M. Partch, "The decline of takeovers and disciplinary managerial turnover," Journal of Financial Economics, Vol. 44, pp. 205-228, 1997.

42. Peck, S. W. "The influence of professional investors on the failure of management buyout attempts," Journal of Financial Economics, Vol. 40, pp. 267-294, 1996.

43. Ryngaert, M., "The effect of poison pill securities on shareholder wealth," Journal of Financial Economics, Vol. 20, pp. 377-417, 1988.

44. Shleifer, A. and R.W. Vishny, "Large shareholders and corporate control," Journal of Political Economy, Vol. 94, pp. 461-488, 1986.

45. Smith, Abbie J., "Corporate ownership structure and performance: The case of management buyouts," Journal of Financial Economics, Vol. 27, pp. 143-164, 1990.

46. Song, M. H. and R. A. Walking, "The impact of managerial ownership on acquisition attempts and target shareholder wealth," Journal of Financial and Quantitative Analysis, Vol. 28, pp. 439-458, 1993.

47. Stulz, R. M., "Managerial control of voting rights: Financing policies and the market for corporate control," Journal of Financial Economics, Vol. 20, pp. 25-54, 1988.

48. Walking, R. A., "Predicting tender offer success: A logistic analysis," Journal of Financial and Quantitative Analysis, Vol. 4, pp. 461-478, 1985.

49. Yermack, D., "Do corporations award CEO stock options effectively?" Journal of Financial Economics, Vol. 39, pp. 237-269, 1995. 